\title{
EU support reductions would benefit California tomato growers and processors
}

by Bradley J. Rickard and Daniel A. Sumner

Many countries apply import barriers for processing tomatoes, but the European Union is the main producer that uses export and production subsidies. We modeled and measured the potential impacts on global markets and the California industry that would result from reductions in trade barriers (such as import tariffs) and subsidies for the European Union's processing tomato industry. A multiequation simulation model showed that reducing trade barriers in Europe and elsewhere (including the United States) by $50 \%$ would raise the market price for California tomatoes by about $6 \%$, improve net returns to California processing tomato producers by $\$ 34$ million per year, and improve net returns to California tomato processors by $\$ 19$ million per year. We also found that a $50 \%$ reduction in $E U$ domestic support would improve the net returns of California producers and processors by about $\$ 8.5$ million per year. Based on these results, we believe that negotiating reductions in subsidies, and especially in global trade barriers, would make economic sense for the California processing tomato industry.

alifornia produces $95 \%$ of the processing tomatoes grown in the United States, and the processing tomato industry is an important component of California agriculture. Its total revenue was $\$ 670$ million in 2004, ranking processing tomatoes 11th among all agricultural commodities produced in California (USDA 2005). Processed tomato products are also a major California export commodity.

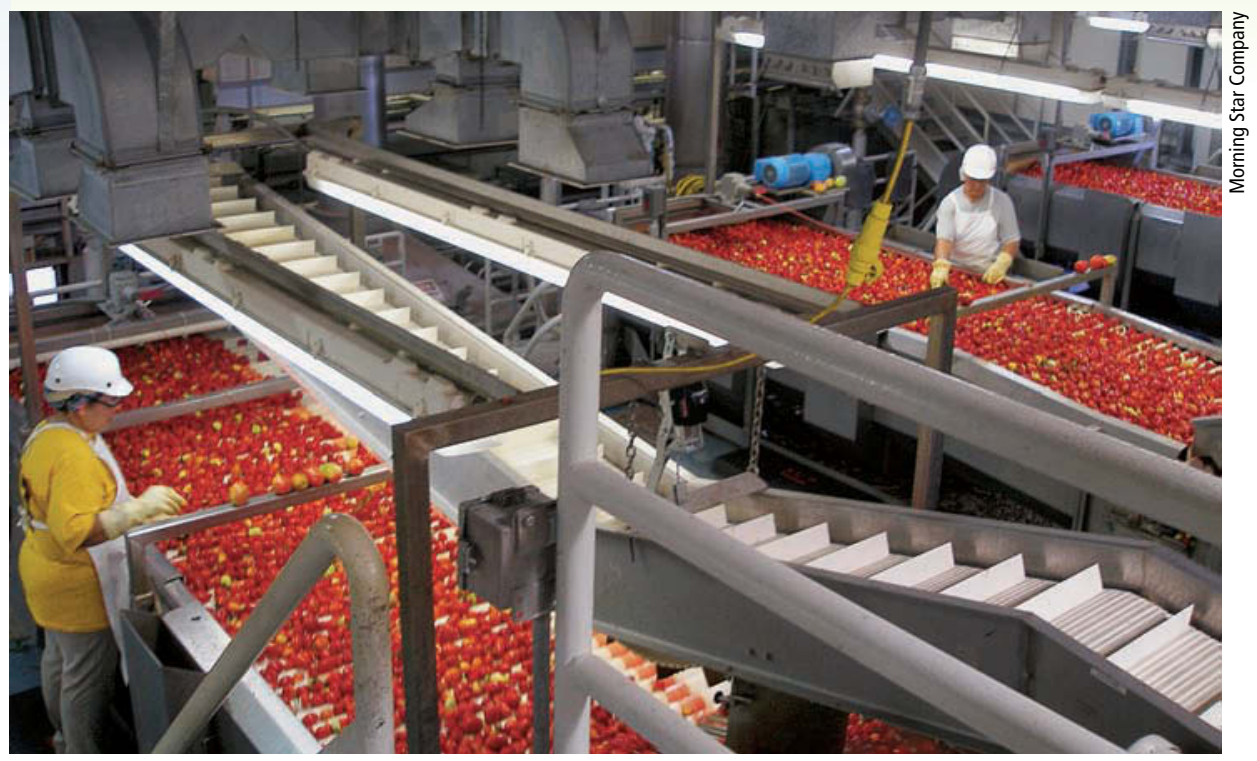

California growers produced $\$ 670$ million worth of processing tomatoes in 2004, making it the state's 11th most valuable crop. More than $10 \%$ of the California crop is processed into products for export, such as tomato paste and sauce.

About $\$ 250$ million of processed tomato products were exported in 2004, accounting for approximately $12 \%$ of the crop; the industry ranked eighth among California agricultural commodities in value of exports (Bervejillo and Sumner 2005).

The United States and European Union each supply approximately one-third of the world's processing tomatoes (fig. 1). There is little or no direct subsidy for processing tomatoes in the United States; however, processing tomato production is directly subsidized in the European Union with payments to growers. The EU subsidy regime for processing tomatoes is part of their overall system of subsidy, which also applies to other fruit and vegetable industries.

We investigated the consequences of EU processing tomato subsidies and global trade barriers for tomato producers and processors, especially in California. Through a simulation model, we show quantitatively how the removal of EU production subsidies would reduce EU production and exports, and raise prices in the global market. We also show that trade barriers (such as import tariffs) have even larger effects than subsidies.
The Doha Round of trade negotiations under the World Trade Organization (WTO) contained a number of proposals to reduce agricultural subsidies, lower import barriers and eliminate export subsidies on a global basis. A relevant option based on the discussions in those negotiations includes the following: eliminating export subsidies and a 50\% cut in both tariffs and domestic support for agricultural commodities (WTO 2004). Our analysis shows what the California processing tomato industry can expect if these negotiations are successful in reducing EU subsidies and protection.

\section{Support for EU industry}

The EU policy for processing tomatoes includes domestic support in the form of subsidies, import tariffs and an export subsidy (European Commission 2005). The subsidies are payments tied to the production of processing tomatoes. Import tariffs are a tax applied to processed tomato products entering the European Union, and export subsidies are paid to EU processors for selected tomato products that are exported. From 1978 to 2000, EU domestic support included a complex array of direct transfers to processors (processor aid), 


\section{Model parameterization}

The proportional changes in prices and quantities are functions of various elasticity and share parameters. (Elasticities are used to represent the ratio between proportional change in one variable and proportional change in another.) The price elasticities of demand for the five processed tomato products were calculated from an overall price elasticity of demand for all processed tomato products, an elasticity of substitution between processed products and consumption shares (Armington 1969). The overall elasticity was set to -0.5 , and was based on estimates from George and King (1971) and Huang (1985). The elasticity of product substitution was set to 5.0, reflecting the fact that tomato products are relatively close substitutes for each other.

The consumption shares were based on per-capita-consumption rates for processed tomato products (USDA 2005). The price elasticity of supply for processing tomatoes was assumed to be relatively inelastic and was set to 0.5 , based on an estimate from Chern and Just (1978). The price elasticity of the manufacturing input supply was set to 1.0. The cost share for processing tomatoes was set to $45 \%$ for tomato paste and $20 \%$ for canned tomato products (based on estimates from a survey of industry experts). We allowed for some substitution between processing tomatoes and the manufacturing input, and this parameter was set to 0.1 . (A value of 0 would indicate no input substitution; for perfect substitutes, the elasticity would be infinite.) The simulation model included raw tomatoes and processed tomato products, and we used a conversion rate of 6.1 tons of tomatoes per ton of tomato paste and 1.2 tons of tomatoes per ton of canned tomato products.

The effects of alternative values of several of these parameters, especially supply and demand elasticities, were also examined to test sensitivity in Rickard (2003). Our results are robust to changes in key parameters across a plausible range, and the main results for the most likely parameter values are reported here.

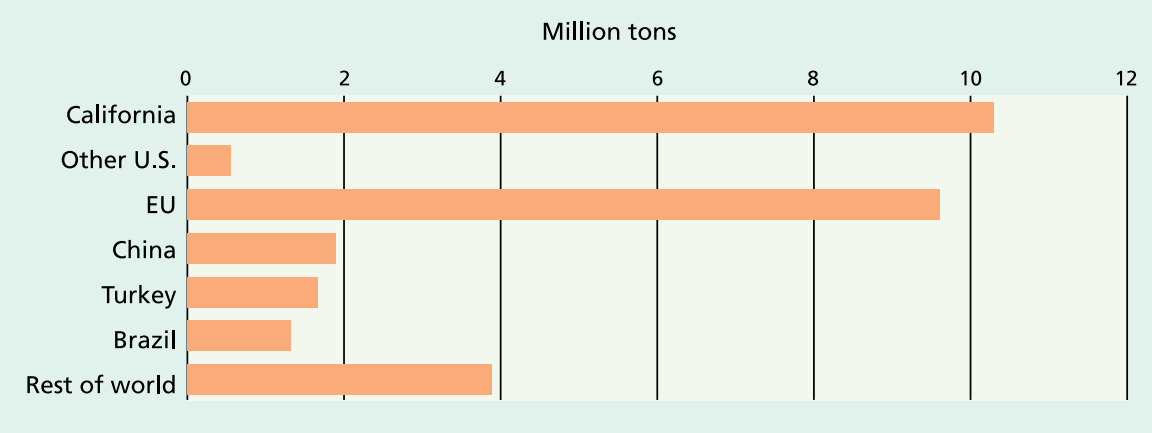

Fig. 1. Average processing tomato production globally, 1999 to 2003. Source: Tomato News 2004.

minimum prices for growers, and a quota that set a limit on the quantity eligible for the processor aid and minimum price. In 2000, processor aid was approximately $\$ 165(€ 163)$ per ton of tomato paste; the minimum price for processing tomatoes was $\$ 81$ ( $€ 80)$ per ton; and the minimum price was applied to approximately 7.7 million tons of processing tomatoes grown in Europe. (In January 2000, \$1 was equivalent to $€ 0.99$; in January 2006, $\$ 1$ was equivalent to $€ 0.82$.)

This subsidy program was changed beginning with the 2001 crop, and the changes have further stimulated EU production (Rickard 2003). Since February 2001, EU growers of processing tomatoes have received a per-ton subsidy from the European Union, as long as total EU production does not exceed the threshold limit of 9.1 million tons (8.25 million metric tons). In 2005 , the subsidy rate was approximately $\$ 39$ per ton and therefore, approximately $43 \%$ of per-unit revenue.

Since 2001, the EU tariff has been set at $14.4 \%$ for processed tomato products such as tomato paste and tomato sauce. The tariff rate has been reduced by onefifth since 1995, in accordance with the Uruguay Round GATT deal, which is administered by the WTO. This tariff is refunded when the imported product is used in, or offset by, exports of processed tomato products. The European Union also allows reduced or zero tariffs for imports from selected developing countries. Export subsidies apply to certain canned tomato products, which make up a relatively small share of total processed tomato production in the European Union. For reference, the United States applies an import tariff of $12.5 \%$ to processed tomato products, and the average (nonweighted) tariff in other tomato-importing regions is approximately $20 \%$.

\section{The simulation model}

We used an economic simulation model to assess the effects of lower EU domestic support and reduced border measures on the global processing tomato industry. There are three regions in our model: the European Union, the United States and the rest of the world. The model accommodates five processed products that are less-thanperfect substitutes for each other in consumption: (1) European Unionproduced canned tomato products, (2) canned tomato products from other sources, (3) European Union-produced paste, (4) U.S. paste and (5) paste produced in other countries. In each of the three regions, two inputs (raw tomatoes and other inputs) are used in the production of these five processed tomato products. There is trade among the regions in processed tomato products but not in raw tomatoes.

The simulation model is used to perform experiments in policy reform; that is, to examine the effects that alternative policy scenarios would have on the processing tomato industry. We focus on reductions in domestic subsidies, export subsidies and tariffs. The European Union has the world's only significant program of domestic subsidies for processing tomatoes, but many countries, including the United States, have import tariffs. It is implausible that import tariffs in the European Union would fall unilaterally; therefore, we considered multilateral reductions in import tariffs across all tomato-producing regions, 
TABLE 1. Simulated effects of policy changes on prices and quantities

\begin{tabular}{|c|c|c|c|}
\hline \multirow[b]{2}{*}{ Variable } & \multicolumn{3}{|c|}{$50 \%$ reduction in: } \\
\hline & Import tariffs & $\begin{array}{l}\text { EU domestic } \\
\text { support }\end{array}$ & $\begin{array}{l}\text { Import tariffs + } \\
\text { EU domestic support }\end{array}$ \\
\hline & 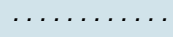 & $\%$ change. & \\
\hline \multicolumn{4}{|l|}{ EU tomatoes } \\
\hline Grower price & 1.4 & -9.3 & -7.9 \\
\hline Processor price & 1.4 & 12.2 & 13.6 \\
\hline Quantity & 0.7 & -4.6 & -3.9 \\
\hline \multicolumn{4}{|c|}{ EU processor inputs } \\
\hline Price & 0.8 & -3.1 & -2.3 \\
\hline Quantity & 0.8 & -3.1 & -2.3 \\
\hline \multicolumn{4}{|l|}{ U.S. tomatoes } \\
\hline Price & 6.2 & 1.0 & 7.2 \\
\hline Quantity & 3.1 & 0.5 & 3.6 \\
\hline \multicolumn{4}{|c|}{ U.S. processor inputs } \\
\hline Price & 3.4 & 0.5 & 3.9 \\
\hline Quantity & 3.4 & 0.5 & 3.9 \\
\hline
\end{tabular}

\begin{tabular}{|c|c|c|c|}
\hline \multicolumn{4}{|c|}{$\begin{array}{l}\text { TABLE 2. Simulated effects of policy changes } \\
\text { in the U.S. processing tomato industry* }\end{array}$} \\
\hline \multirow[b]{2}{*}{ Benefit or cost to: } & \multicolumn{3}{|c|}{$50 \%$ reduction in: } \\
\hline & Import tariffs & $\begin{array}{l}\text { EU domestic } \\
\text { support }\end{array}$ & $\begin{array}{l}\text { Import tariffs + } \\
\text { EU domestic support }\end{array}$ \\
\hline & \multicolumn{3}{|c|}{$\ldots \ldots \ldots \ldots$ change in U.S. \$ millions } \\
\hline $\begin{array}{l}\text { U.S. tomato } \\
\text { producerst }\end{array}$ & 34.6 & 5.5 & 40.3 \\
\hline $\begin{array}{l}\text { U.S. tomato } \\
\text { processors }\end{array}$ & 18.9 & 3.0 & 22.0 \\
\hline $\begin{array}{l}\text { U.S. govt. budget } \\
\text { (tariff revenue) }\end{array}$ & -2.4 & -1.6 & -3.2 \\
\hline $\begin{array}{l}\text { U.S. consumers of pro- } \\
\text { cessed tomato products }\end{array}$ & -19.8 & -6.2 & -24.6 \\
\hline Total U.S. economy & 31.3 & 0.6 & 34.5 \\
\hline
\end{tabular}

combined with reductions in EU export subsidies and EU domestic support.

The simulation model used a set of equations to describe the supply and demand conditions for the processing tomato sector. Equilibrium adjustments can be simulated by specifying changes in the policy parameters, such as changes to EU domestic support or tariff rates. The model is used to simulate proportional changes in prices and quantities (and ultimately benefits or costs to producers and processors) for selected input and output markets in the processing tomato industry (see box, page 208).

\section{Effects of policy reform}

The simulation results describe how changes in EU export subsidies, global tariffs and EU domestic support would affect prices, quantities and net benefit measures, such as revenues and government expenditures. The focus is on the effects in the European Union and, especially, in California.

Export subsidies. The complete elimination of export subsidies would lower EU export tonnage by only $0.6 \%$. The small impact of export subsidy reform is mostly attributed to the fact that the export subsidy rate is low and applies to only a small portion of total EU production. Because the impact of the EU export subsidy on the California industry is so small, the rest of our analysis focused on the effects of reductions in import tariffs and EU domestic support.

Tariffs. We found that a 50\% cut in tariffs would increase the price and quantity produced in the European Union and the United States because both would export more to third markets, which begin with higher tariff rates (table 1). The price and quantity of processor-supplied inputs would also rise.

Domestic support. If EU production subsidies were cut by $50 \%$, we found that per-unit grower returns in the European Union would fall, and market prices paid by EU processors for tomatoes would rise by $12.2 \%$ (table 1 ). The result is a decline in the quantity of tomatoes used and a decline in processor-supplied lion per year for U.S. growers and $\$ 3.0$ million per year for U.S. processors.

The reduction in tariffs on a global basis would have a significantly larger effect on tomato producers and processors in the United States. The benefit to U.S. producers of tomatoes would be approximately \$34 million per year, with about $\$ 32$ million per year of that for growers in California. The increase in benefits to U.S. processors would be approximately $\$ 19$ million per year, with almost all of

\section{Negotiating reductions in subsidies, and especially in global trade barriers, makes economic sense for the California processing tomato industry.}

inputs as well. Cutting EU domestic support by this magnitude would have positive effects in the United States.

Import tariffs and domestic support. If the European Union cut production subsidies and all countries cut tariffs, there would be an increase in the price paid for tomatoes and a decrease in the price received by growers in the European Union (table 1). Reducing global tariffs and EU subsidies together would raise prices and quantities in the United States.

Benefits to U.S. producers and processors. The changes in prices and quantities (table 1) were then used to calculate changes in net producer revenues, net government expenditures or tariff revenues, and consumer benefits from tomato consumption in the United States (table 2). The annual net benefits to producers and processors from cutting the domestic subsidy in the European Union would be $\$ 5.5$ mil- that amount again benefiting California processors. Benefits to tomato producers and processors would total $\$ 53.5$ million per year. Part of this net revenue increase would come from U.S. markets and part from additional export revenue. The cost to U.S. consumers from higher prices for U.S. tomato products would be about $\$ 20$ million. The United States would also lose \$2.4 million in tariff revenue, so the net gain for the United States would be about $\$ 31$ million per year.

\section{Implications for the U.S. industry}

Farmers and processors in the United States would benefit more from reductions in import tariffs than from reductions in EU domestic support, even though that would also mean reductions in the U.S. tariff. However, reductions in import tariffs would place pressure on the EU domestic support regime. Reducing import tariffs would increase the production of tomatoes 

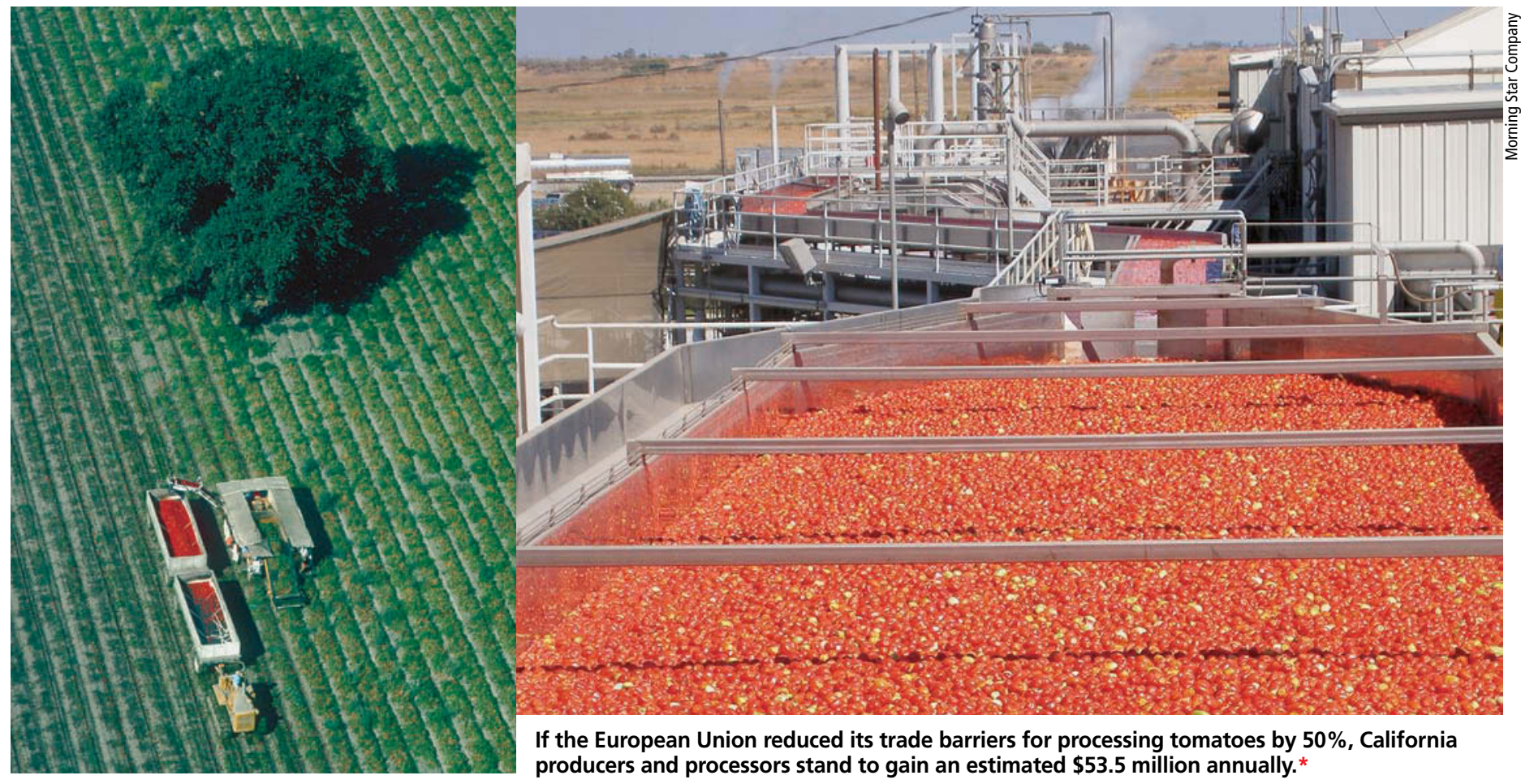

If the European Union reduced its trade barriers for processing tomatoes by $50 \%$, California producers and processors stand to gain an estimated \$53.5 million annually.*

in the European Union, and thereby increase the taxpayer cost of the EU domestic support regime. This would place additional pressure on EU budgets that could lead to reductions in subsidies as a response.

Producers and processors in the United States would gain about $\$ 8.5$ million annually from a reduction in the EU subsidies, and the gain from tariff elimination would be even larger. This result of the simulations may seem surprising, because the initial tariff is only $14.4 \%$, while the subsidy is $43 \%$. The relative magnitude of the two impacts is driven by three factors.

First, the supply response of processing tomatoes in the European Union to lower per-acre returns (including policy benefits) is relatively inelastic in the intermediate time-frame because - for this analysis, and in the context of trade negotiations - we envision reductions in support for processing tomatoes as part of a larger, multicommodity package. Second, EU domestic support applies to the farm-produced product, and import tariffs apply to processed products. The farm product represents only $45 \%$ of the cost of tomato paste and $20 \%$ of the cost of canned tomato products, and barriers that apply at the border have bigger effects on trade than do subsidies for raw materials that are inputs to the tradable product. Third, the EU domestic support program drives a wedge between the price that growers receive and the price that processors pay for tomatoes. Reducing EU domestic support would reduce that wedge, and the burden of any reduction would be shared between the grower and processor.

\section{Effects of trade negotiations}

Trade negotiations have the potential to reduce trade barriers and farm subsidies on a global basis. The California processing tomato industry has long been concerned with subsidies and import barriers in the European Union. Our research shows that this interest is well placed, and although the effects of domestic subsidies are significant, to increase net returns the negotiations should emphasize trade barriers more than domestic subsidies in Europe. We also show that the California processing tomato industry would receive considerable benefits from global tariff reductions, even though that would mean giving up some of its own protection from imports.

B.J. Rickard is Assistant Professor, Agribusiness Department, California Polytechnic State University, San Luis Obispo; and D.A. Sumner is Director, UC
Agricultural Issues Center, and Frank H. Buck, Jr., Chair Professor, Department of Agricultural and Resource Economics, UC Davis.

\section{References}

Armington PS. 1969. A Theory of Demand for Products Distinguished by Place of Production. IMF Staff Papers 16 (March):159-76. International Monetary Fund, Washington, DC

Bervejillo JE, Sumner DA. 2005. California's International Agricultural Exports in 2004. AIC Brief 30. UC Agricultural Issues Center, Davis, CA.

Chern WS, Just RE. 1978. Econometric Analysis of Supply Response and Demand for Processing Tomatoes in California. Giannini Foundation Monograph 37. UC Berkeley, Berkeley, CA.

European Commission. 2005. Agricultural Markets: Fruits and Vegetables. http:/europa.eu.int/comm/ agriculture/markets/fruitveg/index_en.htm (accessed Aug. 15, 2006). Brussels, Belgium.

George PS, King GA. 1971. Consumer Demand for Food Commodities in the United States with Projections for 1980. Giannini Foundation Monograph 26. UC Davis, Davis, CA.

Huang KS. 1985. U.S. Demand for Food: A Complete System of Price and Income Effects. USDA Economic Research Service, Washington, DC. Tech Bull 1714.

Rickard BJ. 2003. Domestic support and border measures for vertically linked and differentiated goods: An examination of EU policy in the processing tomato industry. Ph.D. dissertation. UC Davis, Dept. of Agricultural and Resource Economics.

Tomato News. 2004. Worldwide production of tomatoes for production: 1990 to 2003. www.tomatonews.com/processing.php.

[USDA] US Department of Agriculture. 2005. National Agricultural Statistics Services. Agri Stat. www. usda.gov/nass/pubs/agstats.htm (accessed Aug. 15, 2006).

[WTO] World Trade Organization. 2004. Decision adopted by the General Council on 1 August 2004. WT/ L579, Geneva: WTO. www.wto.org/english/tratop_e/ dda_e/draft_text_gc_dg_31july04_e.htm\#par1b. 